\title{
Infertility Treatment via In -Vitro Fertilization: A Juristic Analysis of Unwanted Embryo Destruction
}

\author{
Dr. Sayed Sikandar Shah Haneef \\ Professor, Department of Islamic Studies, International Islamic University, Malaysia \\ Email: sayedsikandar@iium.edu.my \\ Dr. Mohd Abbas Abdul Razak \\ Affiliation: Kulliyyah of Islamic Revealed Knowledge and Human Sciences, \\ International Islamic University Malaysia \\ Email: maarji@iium.edu.my

\section{Dr. Hayatullah Laluddin} \\ Professor, Kulliyyah of Economics and Management, International Islamic University \\ Malaysia \\ Email: hayatul@iium.edu.my
}

\begin{abstract}
:
In Vitro Fertilization (IVF) has emerged as one of the most popular byproduct of Assistant Reproductive Technology (ART) in our time. It has proven attractive to people across the globe for variety of reasons including infertility treatment and pre-natal sex selection. People of various cultures have reacted to its use in line with their own code of morality and religious values on human procreation, sexual purity and lineage exactitude. In the case of Muslims, its application in the overcoming infertility has received general juridical approval with minim number of caveats. A cursory of the existing fatwas, however reveals that the juristic deliberation on the implications of IVF in terms of destroying the excess embryos generated in the process is scanty. Accordingly, this study argues that if we equate legitimate use of IVF with natural way of human reproduction, then the ethicality of its casualties in terms of surplus embryo destruction should not be trivialized.
\end{abstract}

Keywords: Embryo, In Vitro Fertilization, Gap, Juristic Discourse,

\section{Introduction}

Medical technology as an evolving science speedily innovates not only safe human life and improve health but is poised to bring changes to the old ways/natural ways of doing things including human procreation. This being the case, people's old traditional beliefs and norms need to grapple with such novelties especially if such scientific innovations come into frontal clash with 
their scripturally prescribed traditions. In the case of Muslims, the religious establishment, namely the houses of fatwa are leading the way. The critics, however, believe that the fatwa agencies' approach to contemporary biomedical issues is segmental and one-dimensional in the sense that medical issues are mostly viewed from a micro aspect, purely fiqhi legal angle. Biomedical issue are studied without much reflections on their most obscuring ramification on Muslims' interlinked doctrines of faith, ethics and law, thus producing a patchwork of paradoxical juridical rules (fatwas) which instead of guiding Muslims to the path of correct use of such facilities, paving the way for misusing them by less religious people ${ }^{1}$. Hence, the macro aspect of biotechnologies in terms of creating new lifestyles, consequential encroachment core ethical values on human life, human procreation and sexing are not much reflected upon.

In the context of this paper, IVF for example, since its first successful use leading to the birth of Louise Brown in the United Kingdom in $1978,{ }^{2}$, it has become popular and is welcomed by people around the world. Its moral premium lies on its capability to overcome barrenness( aqm) whether inborn or caused by some surgical interventions like abortion or on account of cervical inflammation which is described as a kind disability in female gender ${ }^{3}$. Hence it is also well received by Muslim populace due to numerous socio psychological variables. For instance, in Muslim culture children are the most valuable assets in one's life in terms of inheriting one's property, carrying female names, sharing the labor, and being a source of social security at old age and foremost continuing the good work of the parents as part of the community of Muslim faith. It is also specifically of utmost psychological and social benefit for Muslim wives, in terms of social prestige, marital harmony, and security against divorce and becoming a co-wife in this age ${ }^{4}$. Utilitarian use of this facility not only helps to overcome fertility but also allows the couple to predetermine the sex of their babies. More possibilities, such as preventing noncommunicable genetic diseases and wanting a child of specific talent and complexion are within ART's arsenal, thanks to the innovators of genetic modification and genome manipulators.

At the ethico-religious level, however, it has triggered intense debate involving its technical procedures across the cultures. In the case of Islam, both Sunni and Shi $i$ schools of jurisprudence, have given juridical approval to it albeit the difference on the list of caveats as parameters for its regulated application by two main sects in the Muslim world.

However, since the jurists especially the official houses of fatwas in the Sunni world, , rely on opinions by the physicians on the biomedical issues such as IVF, it seems that they miss out on some of the most juridical ethical issues like the procedures of baby making(Test Tube babies/atfal al-anabib). This 
most neglected question is the scarcity of juridical discussion on destruction of the surplus lab-created embryos ${ }^{5}$ or aborting extra-foetuses in case of multiple pregnancies (in the name of pregnancy reductions).

Accordingly, in this paper, we delineate the technical aspect of IVF together with Muslim juridical responses about its use with the ultimate aim of deliberating on its factual and potential risks on human embryo destruction.

\section{Methodology}

In view of the nature of the subject matter in consideration, the research employed a qualitative method of analysis. It used library and some field reports for data collection. To unravel as to what is the thrust of contemporary Muslim jurists on the issue, library research was necessary. In this process, a sociological study of the Islamic jurisprudence was adopted via textual analysis approach. This approach engaged with arguments of both opponents and proponents in terms of their legal evidences from both primary sources, of the Qur'an, and Sunnah and subsidiary sources, such as qiyas and maslahah. To bolster the premium of ethical arguments against less restrictive classical legal views on ill-effects of In Vitro Fertilization, applied biomedical findings were analyzed.

The collected data was thematically categorized and then analyzed using textual analysis method. It involved an appraisal of permissive and prohibitive views on IVF. Then it was contextualized to address destruction of surplus embryos as well as aborting malformed and extra fetuses in case of multiple pregnancies.

\section{Result and Discussion}

This issue involves three main themes, namely the technical procedure of IVF, juristic responses about its permissibility and the question of medical destruction of the excess embryos:

1-IVF Technical Procedures

IVF is a complex invasive procedure of infertility treatment for numerous clinical reasons/conditions attributed to one or both of the intending couples. Female clinical conditions warranting IVT include: fallopian tube damage or blockage; ovulation disorder, premature ovarian failure, endometriosis (uterine tissue factor), uterine fibroids(tumor), previous tubal and sterilization or removal. The singular male condition requiring IVF is semen impairment or function. The common cause to both genders are: the passing sexlinked genetic disorder to the offspring and unexplained reason for barrenness (Mayo Clinic Staff, 2018).

This process is rigorously lengthy. It involves numerous tests, such as sperm test, uterus test and strict disciplines, such as pre-cycle birth control measure for duration of a month before the actual procedure. The steps are: first, after a month long use of oral contraception, the doctor employs $\mathrm{GnRH}$ 
argument (a kind of intra- muscular injection) to the female partner to downregulate her hormone control of the ovarian stimulation portion of her cycle. Second, the physician prescribes to the female partner gonadotropins medication to be injected for a duration ranging from 6-12 days. The purpose is to stimulate her ovaries to produce oocytes (eggs) for retrieval. Throughout this cycle, the doctor conducts on her various tests including the fitness of the uterine lining for the implantation of fertilized pre-embryos and also whether she is at risk of developing ovarian hyper stimulation syndrome, causing symptoms, such as dizziness, nausea, weight gain, shortness of breath and others. To enhance the production of the desired type of eggs, the physician shots the patient with human chorionic gonadotropin (hCG) injection 36 hours before the egg retrieval. Additionally, and depending on the female partner's health conditions, other supplements, such as estrogen, baby aspirin to facilitate the process will also be given to her. Thirdly, the egg retrieval usually be done vaginally unless the patient's condition requires it to be done abdominally. Vaginal egg retrieval is an ultrasound-guided procedure. Ultrasound helps the needle to locate the oocytes within the follicles. Usually this procedure take 30 minutes during which the patient is anesthetized. Fourth, the retrieved eggs are handed to an embryologist who separates the eggs from the fluid and then starts the process of its fertilization with the prepared specimen of the semen. The physician, either places the eggs and the sperm in the petri dish to progress to fertilization, or uses an intracytopalsmic sperm injection to fertilize the eggs. The latter is normally used for preimplantation genetic diagnostic(PGD) to ensure that one sperm joins with an egg. Within 72 hours from the egg retrieval, the lab produces up to seven celled embryos. Through PGD, the potency of such embryos for pregnancy would be predicted. Finally, depending on the age of the patient, according to standard procedure, up to three of the good quality preembryo blastocyst are transferred into the patient's uterus(Ebrahim, p.94). Given the propensity on the part of most Muslims for a preferred sex, only the blastocyst of the preferred sex genome predictable on the basis of their chromosomes (XY or XX), would be transferred to the wife's uterus.

However, the procedures are not only invasive but comes with their own documented risks which include: multiple births with attendant consequences of early labor, premature birth and low birth weight( especially in the case of older women at their 40s); ovarian hyperstimulation syndrome due to fertility drugs causing nausea, mild pain, bloating, diarrhea and vomiting; bleeding, infection or damage to the bowel, bladder or a blood vessel during the process of egg retrieval via needle; failed pregnancy as the embryo gets implanted in the fallopian tube; lack of assurance that the IVF child be free from birth defects; chances of developing ovarian cancer; and huge financial, physical and emotional stress(Mayo Clinic Staff, 2018). Specifically, for instance, in 
terms of risks on the babies, it is documented that one in every 24 multiple pregnancies result in the birth of one premature baby and one in 13 would be handicapped. Moreover, IVF babies will be smaller than average babies born naturally. This would have long term effect on them as they are more likely to develop high blood pressure, heart disease, stroke and possibility osteoporosis at a slightly younger age than is usual, perhaps 50-60 years old. And the risks on the mothers would be preterm labor, high blood pressure, gestational diabetes and other related complications ${ }^{6}$. To top it all, the procedures are not one-go affair but the physician deal with female sexual system in several ethically questionable ways, such as conducting ultrasound to her ovaries to test its response to fertility drug; and conduct mock embryo transfer to gauge the depth of her uterus on top conducting hysteroscopy(involving vagina and cervix) right before the start of IVF procedures(Mayo Clinic Staff, 2018). But the most ethically puzzling consequences of IVF is the issue of dealing with surplus embryo which are either frozen for future IVF or discarded to the trash bin. Corollary to this is the decision of fetal reduction when there is multiple pregnancy on account of which we will critique IVF later on ${ }^{7}$.

\section{2-Muslim Juridical Responses}

Being oblivious of its proven clinical risks and moral hazards, the majority of Sunni jurists allow it with one caveat only, namely it does not involve a third party (gamete donor). This is the official opinion adopted by International Islamic Fiqh Academy(IIFA) affiliated with OIC in October 1986, when it resolved: "IVF is legitimate as it does not involve third party gamete but a husband and wife's eggs are fertilized in the lab and then transferred to the wife's uterus. ${ }^{8}$ "

Al-Qaradaghi (2006) in explaining the rationale for the above permissibility view observed that the majority of the contemporary Muslim scholars have no qualm against this mode of artificial insemination (IVF) because it involves externa fertilization of the lawfully married couple's eggs and then returning it to the uterus of the wife. It is akin to fertilization of their eggs through natural coitus. And the paternity of the child is assigned to the husband because he/she is created from his own sexual fluid and is born during the subsistence of his marriage. Hence, impregnation of a wife through IVF is a legitimate practice, it is neither a sin nor can be there any hesitation about it(amalan mashru'an la ithm fihi wa la haraj). From this perspective, IVF can be a legitimate way of having offspring who would carry their names, brings meaning to their lives, enhance their psychological and sociological wellbeing and help in sustaining marital harmony between them.

Dissenting views, however maintain the non-permissibility view on account of novelty of the experiment and its probable moral and physical risks 
on the offspring. Because its procedures are riddled with suspicions and prone to misuse. The physician may wilfully or inadvertently compromise on purity of lineage by implanting wrong embryos to one's wife uterus, on top of violating man and woman's grave vaginal privacy ('awrah mughllazah) throughout the procedures. In view of the above, Mustafa al-Zarqa maintains that: " although most contemporary jurists, from among the University professors, muftis and Shariah judges, who wrote and answered queries about IVF, all agreed that it is permissible without any reservation, I beg to differ and record a nonpermissibility stand(580)."

Those permitting, however, stipulated that should not be used for foetal gender selection and embryo trading. $\dot{ }^{9}$. Because God says:

'To God belongs the dominion of heavens and earth. He creates what $\mathrm{He}$ wills. He bestows females upon whom $\mathrm{He}$ wills and bestows the males upon whom $\mathrm{He}$ wills. Or $\mathrm{He}$ couples them in males and females and He leaves barren that He wills. For He is All-Knowledgeable All-Powerful' ${ }^{10}$.

The Shiah with their compromised view on sexual purity which allows mut'ah sees no problem even with a third party involvement in the process. For instance, Ali Khamenei sanctions asexual impregnating a woman with donor's sperm as it does not involve intercourse although the child's paternity cannot be attributed to the husband. This compromise of Islamic sexual purity can be challenged on other legal prohibitions such as the law of intimacy between nonrelated members in the family in the case of a female child as she would be a stranger to the husband. Due to this anomaly, they prefer the donor to be a near relative. Likewise, Kamenei holds that frozen gametes of a husband can be used to impregnate his wife posthumously even if she has remarried ${ }^{11}$. The Shi'ah, also sees no problem with donor's gamete due to its jurists' permissive approach to sexual purity in the Shi'ah paradigm. For instance, Khaminei holds that in case the wife cannot ovulate a donor's egg can be used in spite of biogenetic connectedness of the child to the receiver but if the husband performs mut'ah with the donor, the hurdle will be overcome ${ }^{12}$.

We believe, that Shi ah stand cannot be reconciled with genealogical purity and sexual morality as are unequivocally mandated by the Qur'an and the Sunnnah, thus are ultra vires of the true teachings of Islam ${ }^{13} ;$. .

From the above, it is clear that Muslim jurists, both Sunni and Shiah, do not examine much of other macro implications of IVF such as the process of egg retrieval and egg culturing, process of implantation into the uterus, its use for sexing by choosing the embryo of the desired gender, trafficking of the surplus embryos or their destruction and aborting the additional fetuses in the case of multiple pregnancies etc. We have dealt with some of them in other studies but 
for the purpose of this paper we tackle the destruction of embryos in the context of Muslim jurists`discourse on abortion.

\section{3-Destruction of Surplus Embryos}

Termination of pregnancies by human interference is called induced abortion. It has been known to humans ever since the dawn of human civilization. However, in our time not only its frequency has escalated beyond imagination but also its forms and manifestations have multiplied especially on account of human manipulation of pregnancy through bio-technology. For instance, the fetus conceived via natural coitus is surgically or via hormonal inducement is removed if found to have been malformed or is infected with AIDS. Similarly, the surplus embryos generated in the process of IVF if not frozen for future use are either discorded or used for destructive research (Stem Cell research). Since Muslims normally may not ask for freezing it in view of Muslin practice of small family today or prohibition of their use posthumously, after the couple divorcing or giving it to a third party, our concern here is the question about its abortion- by discarding it, which, among others, raises two question? Does it have sanctity in the context Muslim prohibition of abortion? Or is it different since it is created outside the womb(unnatural way)?

\section{Classical Views}

According to classical jurists, deliberate destruction of janin(baby after conception until after birth is called as ijhad(abortion) or isqat alhaml(terminating a pregnancy) ${ }^{14}$. As such, it has been a topic of juristic discourse among the Muslim jurists since the formative stage of Islamic law. About its legality, the general position is that it is allowed before the stage of ensoulment of fetus. But what is that stage, there are two positions, namely after 120 days and after 40 plus days- based on interpretation of two hadith on gestational development of the fetus in the women. ${ }^{15}$. In view of this divergence, the juristic discussion of abortion presents a dichotomous discourse where on the ethical plane, it is regarded as sinful from the moment of conception but at the legal domain, there are divergent views among the jurists.

At the level of morality, it is contended that all forms of abortions are immoral and illegal as they involve aggression on inviolable human life which starts from the moment of union between sperm and ovum. This is aptly categorical from many provisions of the Qur'an on prohibition of infanticide including: "Kill not your children for fear of want. We shall provide sustenance for them as well as for you. Verily the killing of them is a great $\sin ^{16}$ ;"Kill not your children on a plea of want. We will provide sustenance for you and for them. Come not near shameful deeds whether open or secret. Take not life which God has made sacred except by way of justice and law. Thus He commands you that you may learn wisdom. ${ }^{17}$; "The pledge of the believing 
women that they shall not kill their children. ${ }^{18}$; "And when the female infant who was buried alive is asked for what crime she was killed? ${ }^{19}$.

The above verses condemn the crime of killing a baby after birth which by extension covers the sanctity of the life a human baby even prior to its birth. However, these verses do not specifically spell out the details of culpability for terminating pregnancies which has been inferred from the embryological delineation of fetal growth as established by two passages of the Qur'an and reaffirmed by the Sunnah. For instance, the Qur'an provides:: “And indeed We created man from a quintessence of clay. Then we placed him as a small quantity of liquid (nutfah) in a safe lodging firmly established. Then we have fashioned the nutfah into something which hangs (alaqah). Then We made alaqah into a chewed lump of flesh (mudghah). And We made the mudgha into bones, and clothed the bones with flesh. And then We brought it forth as another creation. So blessed be God, the best to create. ${ }^{20}$ Another passage reiterate the same embryonic stages except that after the stage of mudghah (chewed-likelump) read,and yet incomplete( ghayr mukhallaqah) which differentiates. ${ }^{21}$

The Sunnah affirmed this by stating that, according to one version: "Verily, the creation of each one of you is brought together in his mother's belly for 40 days. Then it remains there as a leech-like structure('alaqah) for a similar [period]. Then it remains there as a lump of chewed flesh(mudghah) for a similar [period]. Then an angel is sent to determine four things for it: sustenance, term of life, whether miserable or lucky ${ }^{22}$. According to another narration of the same: "The creation of each one of you is composed in the mother's womb in forty days, in that (creation) it turns into such a clot, then in that turns into such a mudgha and then Allah sends an angel and orders him to write four things, i.e., his provision, his age, and whether he will be of the wretched or the blessed (in the Hereafter). Then the soul is breathed into him. ${ }^{23}$

The new dimension in the hadith is the mentioning of the angels involvement in the process which according to reading of majority of the jurists marks the infusion of soul into the fetus when it is 120 days old according to the first version and occurrence of the same event without specifying the timeline. This second version is in accord with another hadith which states the coming of angel takes place when the fetus is forty or forty-nine days old. "When the embryo is forty or forty two days, God send an angel to give it shape and craft his senses. ${ }^{24}$ Or according to another report "One of yours creation in the mother's womb is completed after forty days" 25 .

Accordingly, this became a bone of contention among the jurists as to which is the time when the angel breathes the spirit into the fetus. ${ }^{26}$ Noted jurists like Ibn Abidin, al-Qarafi, al-Nawawi and al-Qurtubi, by claiming unanimity of opinions among the jurists, advance the view that it occurs after 120 days. $^{27}$ 
Others nevertheless, dissented by upholding the connotation of the second hadith, i.e., it happens after 40 day or 42 days from the date of conception. ${ }^{28}$

In analyzing the above, al-Qaradaghi maintains that both the conflicting hadith relied upon by the two groups are not explicit as far as the time for ensoulment is concerned. But the fact of the matter is that as far as the embryologic development of the fetus is concerned, the hadith by the second group is in harmony with the scientific finding today. ${ }^{29}$ However, the ensoulment stage is a matter of belief which science has no jurisdiction to determine. Science concludes that human physical anatomy is featured up to forty days or so. To him, unlike the polemics among the classical jurists, the two ahadith imply that the human shape is completed after 40 days but the ensoulment takes place after 120 days. ${ }^{30}$

Joining him, Al-Zindani also maintained that the first hadith which is reported by both al-Bukahri and Muslim is not explicit on the time which marks the formation of bones, flesh and ensoulment for two reasons: first, only the version reported by Muslim mentions the phrase " thumma yakun fi dhalika",i.e., after forty days it runs into flesh and then after the same period it is covered by bones and then after the same duration it is ensouled; second, linguistically "thumma yakun fi dhalika" refers to the collection of one's creation in the womb rather than the occurrence of changes in the fetus within a certain time frame. Otherwise to state that bone structure is formed after 120 or 90 days will be unscientific.

Consequently, some classical jurists like Ibn Qudamah, Ibn Hazm, alShawkani held that a fetus prior to ensoulment is like lifeless matters or blood, and its termination does not amount to taking a human life away and when aborted will not be given funeral prayer. ${ }^{31}$ This represents the view of the vast majority of Hanabilah, Hanafiyyah and Shafi iyyah in contrast to the position by Malikiyyah and some renowned jurists belonging to other three schools, such as al-Ghazali, Ibn Qayyim, Ibn Abidin. ${ }^{32}$ For instance, an embryo has the life of growth and nourishment like a plant before the soul enters into its body. Then it has the sense of perception and volition (which constitute the basis of human life. ${ }^{33}$ More pro-life was Imam al-Ghazali who held that the more fetus grow, the graver will be the degree of culpability in terminating it from the moment of conception till birth. ${ }^{34}$

\section{II-Contextualization to the Issue at hand}

To apply the classical law of abortion, the case of lab-created embryos, if we co-opt prolife views such as that of Ghazlai and Ibn Qayyim, the answer will be clear. Nevertheless, the majority position still will prove as obscurantist unless, the issue is addressed based a dialectic approach by reading those views in the light of medical understanding of the beginning of human life. Viewed from this angle, the main criticism of the classical paradigm are: first, the pre- 
ensoulment pro-abortion jurists were inconsistent when they acquiesced that unlawful destruction of fetus before 120 days though permitted is still a crime where one tenth of the diyah will be due (ghurrah). ${ }^{35}$ Second, it is incapable of addressing contemporary forms of abortion. Capturing this messy situation, alBar, held that the classical jurists ' distinction between animated fetus (ensouled) and inanimate fetus though valid in law raises serious implications in bioethics. It apparently does not only allow voluntary interruption of pregnancy or therapeutic abortion but also sanctions the use of embryonic stem cells for research, gametes and embryos for artificial reproduction. Anees also emphasized this when he advanced the view that the gestational developmental model developed by the jurists is still entangled with the question of preensoulment and post-ensoulment humans. Hence is "behind the time" ${ }^{\text {"3 }}$. The recent scientific paradigm establishes that the stage of conception is fundamental in structuring a blueprint for biological development of an entity called human. The fertilized eggs through the process of heterosexual vaginal intercourse, not only constitutes the first step in human creation, it also determines its genetic traits including its sex at this stage. ${ }^{37}$ This is called zygote which then differentiates and within five days evolves into marula and then blastula which then implants itself into the uterus wall which is then called embryo. Subsequently it develops into the full- term fetus. Moreover, classical framework also poses a daunting task for contemporary Muslim jurists to espouse life-saving rules on new emerging bio-medical technologies such as embryonic stem cell researches, unwanted pregnancies, defective fetuses, disposal of surplus embryos from IVF etc. ${ }^{38}$ Sensing this, Sachedina also maintains that imprecise definition of life and its beginning in the juristic paradigm poses serious ethical questions about embryonic sanctity of a preimplantation embryo (zygote) if diagnosed to be genetically defective, disabled or abnorma $\left.\right|^{39}$. We believe this fear is real as jurists predominantly condone such an abortion before the emolument.

However, if we go by the position adopted by al-Ghazali and other insightful jurists, the dilemma will be overcome as to him every new inanimate has the potential /destined by God to be animated at a later time. This legal stand seems to represent contemporary jurists ' position who in their ruling of aborting debilitating and effective fetuses maintained that although people can choose from among the divergent views of the classical jurists and may opt for abortion during the first 120 days of pregnancy but the rule of prudence dictates its impermissibility unless its continued existence endangers the mother`s life. ${ }^{40}$

\section{Conclusion}

From the above, it is clear that IVF involves a number of serious macroethical questions if scrutinised from a non-medicalised fiqh viewpoint. First, it defies the Qur'anic conception of fertility and bareness which God declared to 
be destined by Him. ${ }^{41}$ Second, it cannot be justified as a medical necessity as fertility impairment which may be caused by pathological conditions in itself, is not a disease. The acute affliction and anguish that result from childlessness also do not classify it as an ailment. Third, the moral cost of IVF through invasive procedures ravaging human sexual privacy cannot be ethically justified. Last but not least, disposal of surplus embryos as the inevitable outcome of IVF or their consequent abortion in case of multiple pregnancies or malformation as we discussed in this study are bigger issues which cannot be triviliased in any ethical deliberations in the fiqh discourse on IVF. Because abortion generally is haram regardless of janin being formed via natural coitus or asexually created in the lab. The fact that biomedical created embryos are created outside the womb, is not the reason that we consider them less protectable from Shariah perspective.

\section{References \& Notes}

1. Raquib, Amana, Maqasid al-Sharia and Technological Policy-making, (2015, p.12)

2. Inhorn, M.(2009). 'Gender, Health and Globalization in the Middle East: Male Infertility, ICS and Men`s Resistance' in Globalization, Women and Health in the Twenty-first Century by Hona Kickbusch et al (ed). Palgrav: Macmillan, (2009, p.115)

3. Pennings, Guido.(2008). "Ethical issues of infertility treatment in developing countries," ESHRE Monographs, Vol.1. (2008, p.16).

4. Ibid, p.120

5 . The only exception is its isolated reference on the subject of destructive research on embryos for the purpose of creating transplantable tissues via stem cell research the discussion of which is out of the scope of this study. See Thomas Douglas and Julian Savulescu.(2009). Destroying unwanted embryos in research. Talking Point on morality and human embryo research at https://www.ncbi.nlm.nih.gov/pmc/articles/PMC2672894/(accessed 20 June 2019)

${ }^{6}$. Bernard, Ethical Issues Arising from Assisted Reproductive

Technologies, at http://www.islamset. com/bioethics / firstvol.html(accessed 7 May2019). (n.d.: p. 338)

7. Ibid p. 350

8. Majallat al-Majama al-fiqhi al-Islami, (1986, Vol.1, No.3, p.423)

9. Anees, Munawar Ahmed.(1989). Islam and Biological Futures. London: Mansell.(1989,p.34), Hathout, 1985,p.22) 


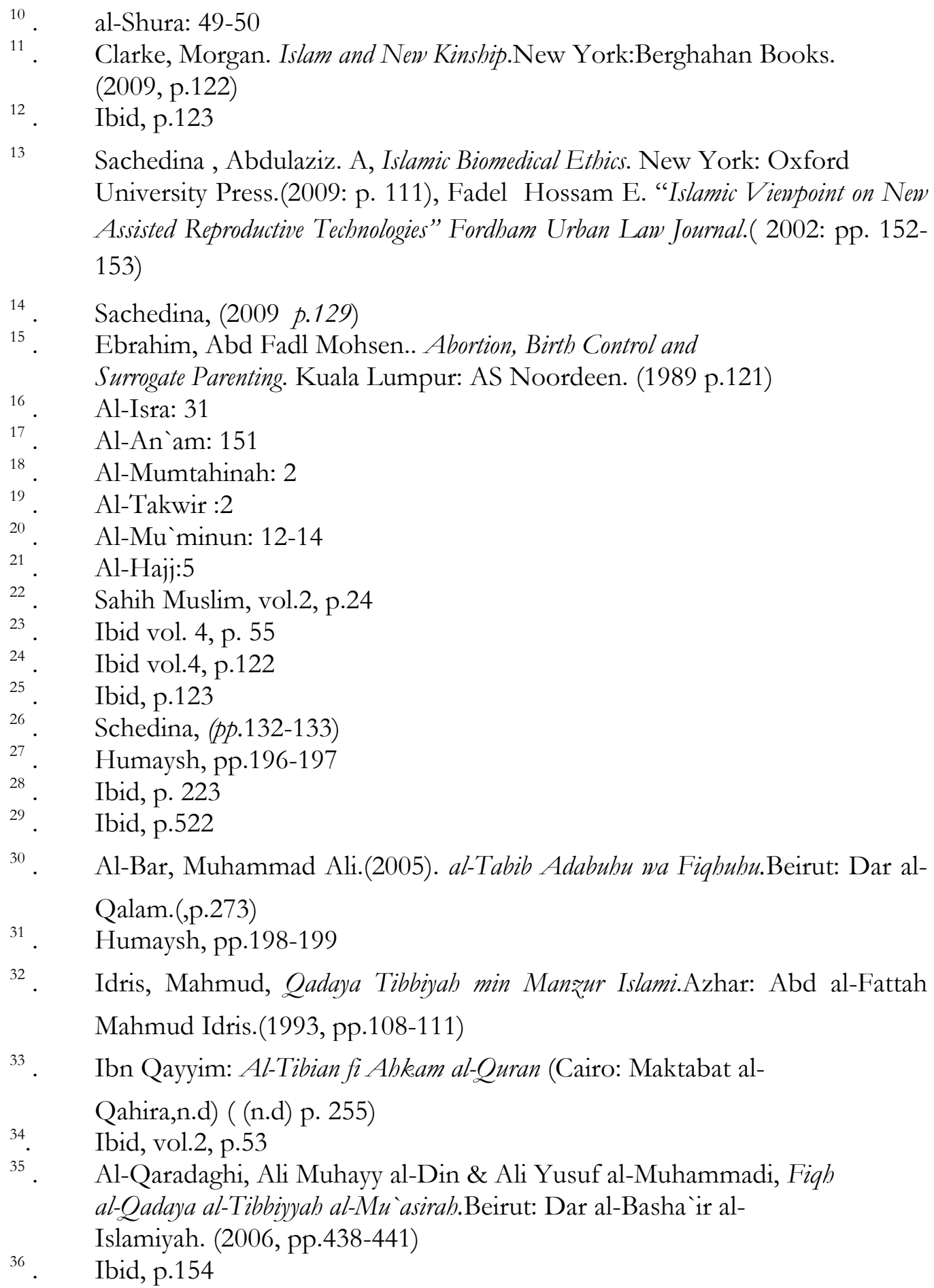




\section{$37 \quad$ Ibid,p.145}

38. Ibid, p.150

39. Schedina, p.125

40 . al-Ashqar, Umar Sulayman "al-Ahkam al-Shar iyyah al-Muta alliqah bi Marad 'Idz,' Umar Sulayman al-Ashqar et al(eds), Dirasat Fiqbiyyah fi Qadaya Tibbiyyah Mu asirah .Amman: Dar al-Nafa is. (2001, pp.66-67

41. al-Shura: 50

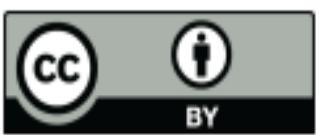

@ 2017 by the author, Licensee University of Chitral, Journal of Religious Studies. This article is an open access article distributed under the terms and conditions of the Creative Commons Attribution (CC BY) (http://creativecommons.org/licenses/by/4.0/). 